\title{
Effect of Peers on Privately Consumed Clothing Itemsof Female Students in a Nigerian University
}

\author{
Imaobong D. Akpan Ph.D, Victoria V. Nkan \\ Department of Educational Foundations, Guidance and Counselling, University of Uyo, Uyo, P.M.B. 1017, \\ Akwa Ibom State, Nigeria \\ Department of Human Ecology, Nutrition and Dietetics, University of Uyo, Uyo, P.M.B. 1017, Akwa Ibom State, \\ Nigeria
}

\begin{abstract}
This study investigated the effect of peers on privately consumed clothing items of female students in University of Uyo, Uyo, Nigeria. Two research questions guided the study. A simple random sampling technique was used to select 710 female students in the University for the Study. Structured questionnaire was used for data collection. Data was analyzed using frequency difference, percentages and ranking. Results of the findings indicated that both normative and informative influences affect decisions to purchase both privately and publicly consumed luxury products, and that there was more influence on normative influence than informative influence in the purchase of clothing items. Based on the results of findings, conclusion and recommendations were made that parents and guardians should inculcate in their children/wards the right values and selfconfidence early in life to enable them make correct and independent choices in life, while teachers should advise their students not to allow peer influences dominate their decision making processes among others.
\end{abstract}

Keywords: Normative influence, Informative influence, Private luxury, private necessity.

\section{Introduction}

There are some people that individual keep in mind when making decisions. Usually such people disseminate opinions and other individuals are pressured into following their trend, becoming associated with them and using them as a standard for their decisions which may include purchase of goods. Such people are known as reference groups and they include entertainment figures, sport heroes, political leaders, parents, coworkers, teachers and peers (Martin and Bush, 2000; Bristol and Mangleburg, 2005; Akpan, Nkan and Usoroh, 2012).

Reference group play a particular role in the life of an individual. They inform and make individual aware of specific products and brands; provide individuals with the attitudes and behavior of the group, and influence individuals to adopt attitudes and behavior that are consistent with the norms of the group. Reference group specify what are desirable as well as undesirable. They also tend to influence product purchase decision, information processing and attitude formation (Lachance, Beaudion and Robitaille, 2003; Yoh,2005). As teenagers mature, they use more sources of consumer information prior to decision making, rely more on friends and less on parents for information and advice on buying and prefer to purchase products without parental supervision. Thus, peer influence could be said to be the extent to which peers exert influence on the attitudes, thoughts and actions of an individual (Makgosa and Mohube, 2007). Peer influence is more noticeable and relevant for high-visibility, high-status products like cars, phones or clothing (Valdez, 2010).

Clothing as one of the fundamentals of life, helps to build and stabilize personality. Man has always endeavoured to provide cover for the body and to do so beautifully (Otong, 2006). It thus becomes an important domain of life in the attraction to a different group of significant others. Appraisals of appearance and actions by peers have become a major concept in the lives of individuals and play a significant role in developing their self concepts. They develop their self concept through conformity to preferred clothing, attitudes and actions (Valdez, 2010). Seeking information, complying with the preference of others, and adopting values of others all involve some form of communication or observation of decisions, opinions or behavior. Several forms of influences exist, but of importance to this study are normative and informative influences. Normative influence refers to the change in behavior due to the anticipation of others' expectations and beliefs, and that an individual will comply with group norms in fear of isolation while informational influence is the influence exerted on consumers who, faced with uncertainty, seek credible sources that can inform their decision and accept information from others as evidence of reality (Valdez, 2010). Peer influence is important in some product purchases which is why there is need to consider the conspicuousness of the product or brand of interest.

Product conspicuousness is a function of two dimensions. First, the extent to which the product is not owned by everybody. Second, the degree to which product usage is performed in public versus in private. Four 
types of products emerge from these two dimensions - publicly consumed luxuries, publicly consumed necessities, privately consumed luxuries and privately consumed necessities (Makgosa and Mohube, 2007).

Privately consumed luxuries are products consumed out of public view and not commonly owned or used while privately consumed necessities are the products that are neither observable nor exclusive because they are consumed out of public view but are used by everybody (Makgosa and Mohube, 2007). These dimensions of product conspicuousness are also applicable to clothing. Examples are sunglasses, weave-on (public luxury), shoe, handbag (public necessity), purse (private luxury), underwear, deodorant (private necessity).

According to Perkinson (1995), the University is described as an academic as well as a social institution. It is expected to solve one's social, economic and political problems. University students on the other hand have exaggerated the need to appear and belong due to influence of peer and other environmental pressure rather than maintain clothing practices that should encourage trust, confidence, comfort, respect and sense of responsibility (Cox and Dietz, 1993).

There are limited empirical studies on influence of peers on clothing purchase decision of female students in Nigeria. Even in the developed countries, related studies are not specific to clothing but to other products. Generally, findings of past studies on peer influence and product purchase decisions have demonstrated that the degree of peer influence differs across products (Bearden and Etzel, 1982; Childers and Rao, 1992; Bachman et al., 1993; Makgosa and Mohube, 2007; Akpan et al., 2012). When comparisons were investigated between products, all the five studies found that the impact of peer influence was stronger for publicly consumed luxuries than for publicly consumed necessities. Privately consumed luxuries also attracted more peer influence than privately consumed necessities.

There are a number of hypothesized influences that were found in each of the five studies that are worth mentioning, as they enhance the understanding of how peer influence vary between products.Bearden and Etzel (1982) showed that informational influence was greater for publicly and privately consumed luxuries than for publicly consumed necessities whereas the effect of utilitarian and value expressive influences were not significant. In addition, publicly consumed luxuries attracted more information, value expressive and utilitarian influences than privately consumed luxuries, which was contrary to the hypothesized influence. However, consistent with the hypothesized influences and equal reference group influence was observed between publicly and privately consumed necessities.

Childers and Rao (1992) also indicated that there is strong and equal peer influence for publicly and privately consumed luxuries which was consistent with the predicted influence. However, contrary to the hypothesized influence, publicly and privately consumed luxuries did not attract a strong peer influence than publicly consumed necessities. A strong peer influence was also found to impact the purchase of publicly consumed necessities than privately consumed necessities.

In a similar study, Bachmann, John and Rao (1993) found that there is an equal peer influence between publicly consumed luxuries and privately consumed necessities among older children (12 years to 14 years). This finding contradicted the hypothesis that publicly consumed luxuries will attract more peer influence than publicly consumed necessities. These authors also found that publicly consumed luxuries and privately consumed luxuries did not have an equal peer influence. Instead, publicly consumed luxuries attracted influence than privately consumed necessities.

Makgosa and Mohube (2007) noted that peer influence is statistically high among University students. Overall findings demonstrated that products that are consumed in public are likely to draw more peer influence than products that are consumed in private but are necessities. However, contrary to the hypothesis specified, the effects of normative and, informative influences were significant between public products. Normatilve influence was also marginally greater for public necessities than for private luxuries.

In a study on peer influence on selected clothing items purchase decision of female student in Uyo, Nigeria, Akpan et al. (2012) noted that normative influence was higher on the decision to purchase public luxury products than informational peer influence. These authors also noted the same outcome for purchase of public necessity. The divergent findings across the five studies could possibly be explained by several reasons

Bearden and Etzel (1982) did not separate various types of reference groups although the influence by parents and peer on products purchases decision differed. Childers and Rao (1992) ts in combined informational, value expressive and utilitarian influence into a single score representing peer influence, yet there is evidence that various types of peer influence will have varying effects on purchase decisions. Bachmann et al. (1993) conceptualized peer influence as comprising of normative influence thus ignoring the significant role of informational influence. Makgosa and Mohube (2007) saw peer influences to be either normative or informational and so did Akpan et al. (2012). The population samples of these authors were also different as well as the location of study.

The reviewed literature suggests that peer influence plays an important role in product purchase decision. However, considering the findings of previous studies, investigating how peer influence varies across products are based on general population, children and young adults. This study is limited to University of Uyo 
female students' consumers. Female students are used in the study instead of the general population, or children because it has been noted by Chang and Chuang (2005) that the influence of peer group gradually becomes important after high school. Female are also more susceptible to the influence of peers since they have limited capacity to cope with risk and uncertainties than their male counterparts (Asuquo, 2010). This study investigatedthe effect of peers on privately consumed clothingitems of female students in University of Uyo, Nigeria. While there are many different sources and types of influence, this study focuses on the normative and informational components of peer influence on two forms of product use - purse and underwear.

\section{Purpose Of The Study}

The main purpose of this study was to investigate the effects of peers on privately consumed items of female students in the University of Uyo, Uyo, Nigeria. The study was designed to achieve the following specific objectives:

- To examine the effect of normative and informative peer influences on the decisions to purchase private luxury product (purse)

- To examine the effect of normative and informative peer influenceson the decisions to purchase private necessity product (underwear).

\section{Research Questions}

1. Do normative and informative peer influences affect decisions to purchase private luxury product (purse)?

2. Do normative and informative peer influences affect decisions to purchase private necessity product (underwear)?

\section{Methodology}

Research design: The survey research design was adopted for the study as the researchers sought the opinions of female University students on the effect of peers on privately consumed items.

Area of study: The study area is University of Uyo, Uyo Akwa Ibom State. The University of Uyo, with the acronym UniUyo is located in Uyo, capital of Akwa Ibom State, Nigeria. It is in the heart of the state capital of Akwa Ibom State, Nigeria's second largest oil producing state. Uyo is easily accessible by roadand air. UniUyo is a federal University and draws students from all over the country.

Population and sample: The population of this study comprised of all female students in the University of Uyo with a Total of seven thousand three hundred and two (7302) for 2011/2012 academic session (Office of Statistics, University of Uyo, 2012). Seven hundred and ten (710) female students were selected from the University. Simple random sampling technique was used in selecting the 710 female students.

Instrument: The instrument used for data collection was a questionnaire titled Questionnaire on Effect of Peers on Privately Consumed Clothing Items (QEPCCI). The instrument was divided into two sections. Each had a four point scale response- Strongly Agree (SA), Agree(A), Disagree(D) and Strongly Disagree (DA). SA was scored 4 points, A was scored 3 points, D was scored 2 points and DA was scored 1 point. Each of the two sections measured both normative and informative influences with four items on the identified clothing items.

Three experts-lecturers in clothing and textiles, child development and test and measurement ascertained the validity of the instrument. Reliability of the instrument was determined through test-retest using the Cronbach's Alpha reliability test which yielded reliability co-efficient of 0.913 which portrayed that the instrument was very reliable.

Data collection and analysis: The researcher and two trained female research assistants administered and retrieved the questionnaires from the respondents. 670 out of the 710 questionnaires distributed were correctly filled and considered valid for use in the study. The analysis was done using frequency difference, percentages and ranking.

\section{Results}

Research Question 1: The first research question stated:- Do normative and informative peer influences affect decisions to purchase private luxury product (purse)?

This question was answered using frequency difference, percentage and ranking. The result is presented in Table 1 . 
Table 1: Percentage analysis of the differences between normative and informative peer influences on decisions to purchase private luxury (purse).

\begin{tabular}{|l|l|l|l|l|l|}
\hline Variables & $\begin{array}{l}\text { Normative } \\
\text { Influence }\end{array}$ & $\begin{array}{l}\text { Informative } \\
\text { Influence }\end{array}$ & $\begin{array}{l}\text { Frequency } \\
\text { Difference }\end{array}$ & Percentage(\%) & Ranking \\
\hline $\begin{array}{l}\text { I do not purchase the latest fashion until } \\
\text { I am sure my friends approve of them }\end{array}$ & 511 & 504 & 7 & $5.04^{*}$ \\
\hline $\begin{array}{l}\text { I achieve a sense of belonging by } \\
\text { purchasing the same item that my } \\
\text { friends purchase }\end{array}$ & 549 & 525 & 24 & 20.17 \\
\hline $\begin{array}{l}\text { To buy the right clothing item, I } \\
\text { consider what my age group are buying } \\
\text { and using }\end{array}$ & 601 & 581 & 20 & 16.81 & $2^{\text {th }}$ \\
\hline $\begin{array}{l}\text { I purchase only clothing items that will } \\
\text { make good impression on my age group }\end{array}$ & 485 & 416 & 69 & $57.98^{* *}$ \\
\hline
\end{tabular}

**The highest difference

* The lowest difference

Table 1 presents the percentage analysis of the differences between normative and informative peer influence on decisions to purchase private luxury (purse).From the analysis, it was observed that purchasing only clothing items that will make good impression on ones age group had the highest difference between the normative and informative peer influence on decisions to purchase private luxury (purse) (57.98\%), followed by achievement of a sense of belonging (20.17\%); considering the item bought and used by age group had the third ranking of $16.81 \%$ and the least was observed in not purchasing the latest fashion until one is sure of friends approval $(5.04 \%)$.

Research Question 2: The second research question stated:- Do normative and informative peer influences affect decisions to purchase private necessity product (underwear)?

This question was answered using frequency difference, percentage and ranking. The result is presented in Table 2 .

Table 2: Percentage analysis of the differences between the effect of normative and informative peer influences on decisions to purchase private necessity (underwear).

\begin{tabular}{|l|l|l|l|l|l|}
\hline Variables & $\begin{array}{l}\text { Normative } \\
\text { Influence }\end{array}$ & $\begin{array}{l}\text { Informative } \\
\text { Influence }\end{array}$ & $\begin{array}{l}\text { Frequency } \\
\text { Difference }\end{array}$ & $\begin{array}{c}\text { Percentage( } \\
\%)\end{array}$ & $\begin{array}{l}\text { Ranking } \\
46.34^{* *}\end{array}$ \\
\hline $\begin{array}{l}\text { I do not purchase the latest fashion until I am sure } \\
\text { my friends approve of them }\end{array}$ & 458 & 422 & 38 & $8.54^{\text {st }}$ \\
\hline $\begin{array}{l}\text { I achieve a sense of belonging by purchasing the } \\
\text { same item that my friends purchase }\end{array}$ & 473 & 466 & 7 & $4^{\text {th }}$ \\
\hline $\begin{array}{l}\text { To buy the right clothing item, I consider what } \\
\text { my age group are buying and using }\end{array}$ & 519 & 494 & 25 & 30.49 & $2^{\text {nd }}$ \\
\hline $\begin{array}{l}\text { I purchase only clothing items that will make } \\
\text { good impression on my age group }\end{array}$ & 314 & 302 & 12 & 14.34 \\
\hline
\end{tabular}

**The highest difference

*The least difference

Table 2 presents the percentage analysis of the differences between the effect of normative and informative peer influences on decisions to purchase private necessity (underwear).From the analysis, it was observed that the highest difference between the normative and informative peer influence on decisions to purchase private necessity (underwear) was (46.34\%), from "I do not purchase the latest fashion until I am sure my friends approve of them'. Consideration of what the age group buys and uses followed with $30.49 \%$. The third ranking was $14.34 \%$ with the variable of purchasing only clothing items that will make good impression on the age group. Achieving a sense of belonging by purchasing the same item that friends purchase had the least percentage $(8.54 \%)^{\prime}$ '.

\section{Discussion}

The result from the data on Table 1 connotes that normative and informative peer influences affects decisions to purchase private luxury product such as purse with clear differences indicated between normative and informative influences.

This means that the decision of female students in University of Uyo to purchase private luxury items such aspurse is dependent on their peers' opinion.

This result is in line with the results of findings of Akpan et.al.(2012) and Makgosa and Mohube (2007) as peer influence was found to be statistically significant in decision to purchase public products. Purse being a luxury product is not consumed by every female student which attracts more peer influence. This result also supports 
opinions of Bearden and Etzel (1982) as well as Childers and Rao (1992) who stated that privately consumed luxuries attract higher peer influence because they are luxury and command more purchase.

The result of findings on Table 2 indicates that both normative and informative peer influences affect decisions to purchase private necessity product such as underwear. The study also reveals that there is remarkable normative influence than informative influence on the decision to purchase underwear which is privately consumed. The result is contrary to the opinion of Bearden and Etzel (1982); Childers and Rao (1992) who described privately consumed products as being neither observable nor exclusive since they are consumed out of public view and are used by everybody. They said that such products are not socially relevant and are not likely to be influenced by peers.

The results of this study has also affirmed that both normative and informative peer influences affect private and public luxury products as earlier stated by Yoh (2005) and Lachance et al. (2003) as such products are consumed through the eyes of peers. However, normative peer influences tend to be higher than informative peer influences as far as decision to purchase privately consumed clothing items of female students is concerned.

\section{Conclusion And Recommendations}

Peer influence affects various aspects of everyone's life, clothing choice is one of such. Female students are constantly impacted by those around them within the society especially their friends. The study revealed that normative and informative influencesaffect the selection of clothing items by female students with normative peer influence ranking higher than informative peer influence. Conclusively, female students are more influenced by the norms of their peers than information from their peers.

Based on the findings of the study, the following recommendations are made:

- Parents and guardians should endeavour to inculcate the right values in their children/ wards to enable them acquire self confidence to make good and independent choices in life irrespective of the views from their peers.

- Teachers should advise the students placed under their care not to allow peer influences to dominate their decision making processes except where they require a second opinion.

- Educational awareness should be created through seminars and symposiums where students can be enlightened on the need to place similar value on both normative and informative influences as it affects their purchase decisions.

- Producers of goods and services should explore and inculcate the use of both normative and informative concepts in the advertisement of their products as these affect their acceptability.

- The Nigerian government, through the relevant agency should strictly enforce the policy on product labeling which is very effective in relaying correct information about any product to the consumers.

\section{References}

[1]. Akpan, I. D.; Nkan, V. V. \& Usoroh, C. (2012). Peer Influence on Selected ClothingItems Purchase Decision of Female Students in University of Uyo. Journal of Home Economics Research. 16: 195-202.

[2]. Asuquo, V. F. (2010). Peer Influence on Clothing Purchase Decision of Female Students in University of Uyo. AnUnpublished Dissertation. University of Uyo, Uyo.

[3]. Bachmann, G. R.; John, D. R. \& Rao, A. R. (1993). Children's Susceptibility to Peer GroupPurchase Influence: an Exploratory Investigation. Association in Consumer Research. 20: 463-468.

[4]. Bearden, W. O. \& Etzel, M. J. (1982). Reference Grooup Influence on Product and Brand Purchase Decisions. Journal of Consumer Research, 9: 183-481.

[5]. Bristol, T. \& Mangleburg, T. F. (2005). Not Telling the Whole Story: Teen Deception in Purchasing. Journal of Academics. 33(1): 79-95.

[6]. Chang, L. \& Chuang, H. (2005). The Study of Subculture and Consumer Behaviour: An Example of Taiwanese University Students' Consumption Culture. American Academic Business Journal. 7: 258-264.

[7]. Childers, T. L. \& Rao, A. R. (1992). The Influence of Familial and Peer Based Reference on Consumer Decision. Journal of Consumer Research. 19: 198-211.

[8]. Cox, C. E.\& Dietz, E. G. (1993). Adapting to Teen Culture. Journal of Extension. 21: 72-73.

[9]. Lachance, M. J.; Beaudion, P. \& Robitaille, J. (2003). Adolescents Brand Sentivity in Apparel: Influence of Social Agents. International Journal of Consumer Studies. 27: 47-57.

[10]. Makgosa, R. \& Mohube, K. (2007). Peer Influence on Young Adults' products Purchase Decisions. African Journal of Business Magt. 26: 64-71.

[11]. Martin, C. A. \& Bush, A. J. (2000). Do Role Models Influence Teenagers Purchase Intentions and Behaviour. Journal of Consumer Studies. 17(5): 441-454

[12]. Otong, J. C. (2006). Wither Society: Reflections on some Bugging Social and Demographic Issues in $21^{\text {st }}$ Century Nigeria. Inaugural Lecture. Calabar: Adonai Publishing House Perkinson, H. (1995). The imperfect Panacea. USA McGraw-Hill, p. 92.

[13]. Valdez, A. (2010). Group Influence on Consumer Behaviour. www.chow.com/info-7759516-group-influence-consumerbehaviour.html. retrieved on August 24, 2010.

[14]. Yoh, T. (2005). Parent, Peer and TV. Influences on Teen Athletic Shoe Purchasing. The Sport Journal, 8(1), $42-43$. 